\title{
Penerapan Problem Solving, Berbantuan Drill Method untuk Meningkatkan Hasil Belajar SBK
}

\section{Made Darmiati*}

SMP Negeri 3 Banjar

\section{A R T I C L E I N F O}

Article history:

Received 12 December 2019

Received in revised form

01 January 2020

Accepted 30 January 2020

Available online 27

February 2020

Kata Kunci:

Problem solving. drill

method.

Keywords:

Problem solving. drill method.

\begin{abstract}
A B S T R A K
Penelitian Tujuan penelitian tindakan kelas ini adalah untuk mengetahui apakah penerapan model pembelajaran problem solving, berbantuan latihan keterampilan (drill method) dapat meningkatkan hasil belajar siswa. Penelitian ini dilaksanakan di SMP Negeri 3 Banjar di Kelas IX.12 semester genap tahun pelajaran 2017/2018. Metode pengumpulan datanya adalah observasi dan tes hasil belajar. Metode analisis datanya adalah deskriptif baik untuk data kualitatif maupun untuk data kuantitatif. Hasil yang diperoleh dari penelitian ini adalah : hasil belajar siswa pada awalnya rata-rata hanya 65,50 dengan ketuntasan belajar $29 \%$, selanjutnya setelah pelaksanaan siklus I rata-rata hasil belajar siswa meningkat menjadi 71,68 dengan ketuntasan belajar mencapai $43 \%$, setelah pelaksanaan siklus II terjadi juga peningkatan hasil belajar siswa mencapai rata-rata 80,29 dan ketuntasan belajar $86 \%$. Jadi penerapan model pembelajaran problem solving, berbantuan drill method. Dapat Meningkatkan Hasil Belajar Seni Budaya Siswa Kelas IX.12 Semester Genap SMP Negeri 3 Banjar Tahun Pelajaran $2017 / 2018$.
\end{abstract}

\section{A B S T R A C T}

The purpose of this class action research is to find out whether the application of problem solving learning models, assisted with skills training (drill method) can improve student learning outcomes. This research was carried out at of SMP Negeri 3 Banjarn Class IX.12 even semester 2017/2018 school year. Data collection methods are observation and learning achievement tests. The data analysis method is descriptive both for qualitative data and for quantitative data. The results obtained from this study are: student learning outcomes initially an average of only 65.50 with 29\% mastery learning, then after the implementation of the first cycle the average student learning outcomes increased to 71.68 with mastery learning reached $43 \%$, after the implementation of the second cycle also occurred an increase in student learning outcomes reached an average of 80.29 and $86 \%$ mastery learning. So the application of the problem solving learning model, aided by the drill method. Can Improve the Learning Outcomes of Cultural Arts Students of Class IX.12 Even Semester of SMP Negeri 3 Banjar 2017/2018 Academic Year. 


\section{Pendahuluan}

Melalui pendidikan tercipta sumber daya manusia yang terdidik dan mampu menghadapi perkembangan zaman yang semakin maju. Oleh karenanya kegiatan pembelajaran sangat perlu ditingkatkan, sebab kegiatan pembelajaran sangat menentukan keberhasilan siswa dalam proses belajar.

Dalam proses kegiatan belajar yang bertujuan untuk mengubah tingkah laku peserta didik, dipengaruhi oleh banyak faktor. Faktor-faktor yang berpengaruh, secara garis besar dapat dibagi dalam klasifikasi faktor intern (dari dalam) faktor ekstern (dari luar) diri peserta didik. Kehadiran faktor-faktor psikologi tersebut akan memberikan andil yang cukup penting. Faktor psikologi akan senantiasa memberikan landasan dan kemudahan dalam upaya mencapai tujuan belajar secara optimal. Sebaliknya, tanpa kehadiran faktor-faktor psikologi, bisa jadi memperlambat proses belajar, bahkan dapat pula menambah kesulitan dalam mengajar.

Berhasil tidaknya pengajaran seni budaya juga bergantung pada keberhasilan siswa dalam proses belajar mengajar, sedangkan keberhasilan siswa tidak hanya tergantung pada sarana dan prasarana pendidikan, kurikulum mapun metode. Akan tetapi guru mempunyai posisi yang sangat strategis dalam meningkatkan prestasi siswa dalam penggunaan strategis pembelajaran yang tepat.

Namun kondisi dilapangan sangat berbeda dengan yang diharapkan, salah satu faktor yang mempengaruhi rendahnya hasil belajar seni budaya adalah faktor guru. Lemahnya kemampuan siswa menguasai konsep dasar seni musik, seni rupa maupun seni tari dikarenakan banyak guru mengajar secara konvensional dengan menggunakan metode pembelajaran yang kurang menekankan pada adanya inovasi. Guru perlu mengubah sikap dan pola pembelajaran yang telah dilakukannya. Karena terbukti bahwa kegiatan pembelajaran yang berlangsung selama ini belum mampu menghasilkan proses pembelajaran yang berkualitas dan menghasilkan siswa berprestasi maksimal. Guru selama ini lebih mengutamakan kegiatan pembelajaran yang berorientasi pada kognitif dan sering meninggalkan peran lain seperti afektif maupun perkembangan psikomotorik siswa. Kurangnya perhatian siswa dalam belajar serta kurangnya waktu latihan, hal ini dikarenakan guru kurang optimal menggunakan metode pembelajaran yang bervariasi dan kurang efektif dalam penggunaan waktu pembelajaran.

Dapat dilihat dari hasil observasi peneliti di kelas IX.12, dengan jumlah siswa 28 orang. Rata-rata hasil belajar seni budaya hanya mencapai 65,50 sedangkan nilai ketuntasannya mencapai $29 \%$, hal ini dikarenakan kurangnya pemahaman siswa tentang pelajaran seni budaya. Untuk tingkat keberhasilan siswa dalam mempelajari seni budaya hanya 8 orang (29\%) dari 28 orang sedangkan yang belum berhasil sebanyak 20 orang (71\%). Rata-rata nilai hasil ulangan dan ketuntasan klasikal yang diperoleh jika diukur dengan KKM ternyata tergolong belum tuntas, karena KKM mata pelajaran Seni Budaya pada sekolah ini adalah 78. Maka perlu dipikirkan cara dan strategi untuk mengatasi permasalahan tersebut.

Salah satu alternatif pemecahan masalah diatas yang mungkin untuk dilaksanakan oleh guru adalah melaksanakan pembelajaran seni budaya dengan menerapkan langkah-langkah model pembelajaran problem solving, berbantuan latihan keterampilan (drill method).

Model pembelajaran Problem Solving merupakan salah satu dari banyak cara yang bisa dilakukan guru dalam upaya meningkatkan mutu pembelajaran. Model ini menyatakan bahwa sekolah belajar menggunakan pikiran dengan baik, berpikir kreatif dalam menghadapi persoalan serta menanamkan kebiasaan untuk berpikir. Model pembelajaran Problem Solving lebih banyak memberikan penekanan pada kemampuan berpikir tingkat tinggi. Untuk melakukan ini diperlukan kecerdasan yang baik atau intelektual yang tinggi. Keterampilan intelektual tingkat tinggi dapat dikembangkan melalui pemecahan masalah. Dapat dikatakan bahwa model pembelajaran Problem Solving atau model pemecahan masalah mengupayakan agar siswa dapat melakukan pembelajaran dengan berpikir logis, rasional, kritis, cermat, jujur dan efektif.

Cholis (2002) dalam Dyah Retno Kusuma Wardani (2011:58) menyebutkan ada beberapa hal yang perlu diperhatikan dalam pembelajaran pemecahan masalah yaitu: 1) menentukan permasalahan yang akan disajikan disesuaikan dengan materi, 2) masalah yang disajikan harus mampu mendorong siswa berpikir dari berbagai sudut pandang yang berbeda, 3) masalah harus disesuaikan dengan tingkat kemampuan siswa, 4) masalah harus jelas, 5) masalah dikaitkan dengan dunia nyata dan cukup menarik bagi siswa.

M. Nur (2003) mengatakan bahwa ciri kelas yang melaksanakan pembelajaran adalah: 1) siswa secara aktif terlibat dalam pembelajaran, 2) siswa belajar dari temannya melalui kerja kelompok, diskusi, saling mengkoreksi, 3) pembelajaran menekankan pada masalah bersifat terbuka, 4) perilaku siswa dibangun atas kesadaran diri dan hadiah untuk perilaku baik adalah kepuasan diri, 5) siswa menggunakan kemampuan berpikir kritis dan kreatif terlibat penuh dan ikut bertanggung jawab dalam mengadakan terjadinya proses pembelajaran yang efekif, 6) penghargaan terhadap pengakuan siswa sangat diharapkan. 
Posner (1973) menyatakan Problem Solving atau pemecahan masalah terbagi dalam tiga tahap: representasi masalah, bagaimana kita menangkap, menggambarkan dan mengiterpretasikan suatu masalah; mengatur strategi untuk memecahkan masalah dan merumuskan apakah solusi tersebut memuaskan atau tidak. Beberapa pencetus teori berusaha untuk menjelaskan Problem Solving melalui istilah dari prinsip-prinsip associative learning yang berlaku pada studi tentang clasical dan instrumental conditioning (contohnya, Maltzman, 1955). Maier (1940) membedakan antara memecahkan masalah berdasarkan pada transfer langsung dan memecahkkan masalah dengan mengintegrasikan pengalaman sebelumnya dalam Novel Fashion (productive thinking).

Disamping itu mampu memecahkan masalah yang sedang dihadapi dengan memahami masalah tersebut, membuat perencanaan pemecahannya, menyelesaikan masalah tersebut dengan mengecek kembali langkah-langkah yang bisa diupayakan untuk itu. Siswa mesti diupayakan untuk mampu menggunakan proses berpikir yang lebih jauh dan lebih dalam, terlibat lebih aktif seperti berdiskusi, berprestasi, saling mengoreksi, serta pemberian hadiah oleh guru bagi yang berprestasi. Dan berbantuan latihan keterampilan (drill method) mampu meningkatkan intensitas belajar siswa serta meningkatkan keterampilan siswa agar mencapai hasil yang lebih optimal.

Selain model pemecahan masalah yang bisa dilkaukan sebagai alternative pemecahan masalah di ats dengan memberikan metode drill method. Menurut Asmani (2009:37-38) : Metode latihan (drill) disebut juga metode training, yaitu suatu cara mengajar untuk menanamkan kebiasaan-kebiasaan tertentu. Selain itu, juga dapat digunakan sebagai sarana untuk memelihara kebiasaan-kebiasaan yang baik. Di samping itu, metode ini dapat digunakan untuk memperoleh suatu ketangkasan, ketepatan, kesempatan, dan keterampilan.

Menurut Hamdani (2009:273) : "Metode drill merupakan metode yang mengajarkan siswa untuk melaksanakan kegiatan latihan agar siswa memiliki ketegasan atau keterampilan yang lebih tinggi daripada hal-hal yang telah dipelajari".

Dalam buku Nana Sudjana (1991), metode drill adalah suatu kegiatan melakukan hal yang sama, berulang-ulang secara sungguh-sungguh dengan tujuan untuk memperkuat suatu asosiasi atau menyempurnakan suatu keterampilan agar menjadi bersifat permanen. Ciri yang khas dari metode ini adalah kegiatan berupa pengulangan yang berkali-kali dari suatu hal yang sama.

Menurut Asmani (2009:37-38) : Metode latihan (drill) disebut juga metode training, yaitu suatu cara mengajar untuk menanamkan kebiasaan-kebiasaan tertentu. Selain itu, juga dapat digunakan sebagai sarana untuk memelihara kebiasaan-kebiasaan yang baik. Di samping itu, metode ini dapat digunakan untuk memperoleh suatu ketangkasan, ketepatan, kesempatan, dan keterampilan.

Berdasarkan pendapat tersebut penulis menyimpulkan metode latihan adalah suatu cara mengajar untuk menanamkan kebiasaan-kebiasaan tertentu untuk memperoleh suatu keterampilan secara permanen.

Dengan kelebihan-kelebihan model pemecahan masalah dan drill method maka timbul keinginan sebagai guru untuk mengupayakan peningkatan hasil belajar seni budaya pada kelas IX.12 di SMP Negeri 3 Banjar dengan menerapkan model pembelajaran Problem Solving. Untuk mendapatkan hasil yang optimal, model pembelajaran Problem Solving dapat diterapkan berbantuan latihan keterampilan (drill method) yang mampu mendorong keaktifan siswa dan percepatan daya tangkap siswa terhadap materi yang disampaikan.

\section{Metode}

Penelitian yang dilakukan yaitu penelitian tindakan kelas. Penelitian ini dilaksanakan di Lokasi/tempat diadakan penelitian ini adalah di SMP Negeri 3 Banjar, Kecamatan Banjar, Kabupaten Buleleng. Subjek penelitian ini adalah semua siswa kelas IX.12 SMP Negeri 3 Banjar 28 orang yang terdiri dari 15 orang perempuan dan 13 orang laki-laki Yang menjadi objek penelitian ini adalah peningkatan hasil belajar seni budaya siswa kelas IX.12 SMP Negeri 3 Banjar setelah diterapkan model pembelajaran Problem Solving, berbantuan latihan keterampilan (drill method) dalam proses pembelajaran. Penelitian ini dilakukan dari bulan Januari sampai bulan Maret Tahun 2018.

Penelitian ini adalah penelitian tindakan kelas (classroom action research). Penelitian akan berlangsung dalam dua (2) siklus. Dengan demikian pada siklus ke-n terdapat beberapa tahapan kegiatan. Ebbut 1985 (dalam Kasihani, dkk. 2006: 8) dinyatakan bahwa salah satu karakteristik penelitian tindakan kelas adalah adanya proses pelaksanaan penelitian sebagai suatu rangkaian siklus yang berkelanjutan. Di dalam dan di antara siklus-siklus tersebut ada informasi yang merupakan balikan dari apa yang telah dilaksanakan oleh si peneliti. Proses tersebut merupakan proses yang dinamis, dimana ada empat tahap yaitu: 1) perencanaan tindakan, 2) pelaksanaan atau implementasi tindakan, 3) observasi dilanjutkan 
dengan evaluasi dan analisis dan 4) refleksi. Sederhananaya desain peneletian ini dapat dilihat pada gambar 1.

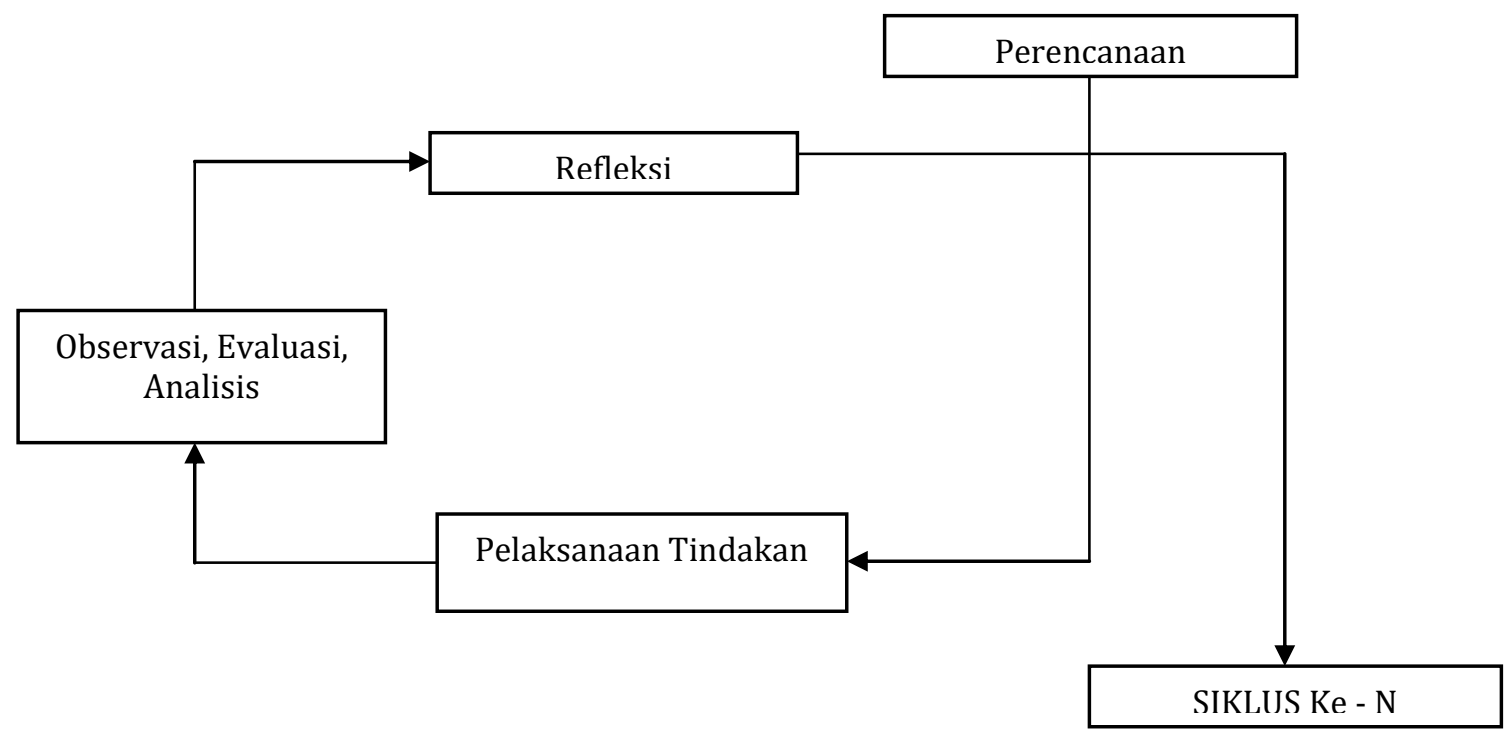

Gambar 1. Desain penelitian tindakan kelas

Evaluasi merupakan kegiatan untuk menilai keberhasilan siswa dengan menggunakan instrumen tes. Evaluasi yang digunakan dalam penelitian ini adalah pre-test dan post-test. Adapun jenis evaluasi yang digunakan adalah dengan menggunakan tes pilihan ganda dengan jumlah soal 20 item dengan option: $a, b$, c, dan d serta dengan bobot masing-masing item adalah satu. Skor Maksimal Idel (SMI) diperoleh setelah skor dari seluruh siswa yang didapatkan, kemudian dari semua skor siswa ditotal dan dibagi jumlah siswanya. Teknik pemberian skor berdasarkan analisis data yang diperoleh melalui post-test tiap akhir siklus.

Melalui evaluasi ini diharapkan hasil belajar siswa mengalami peningkatan dari sebelum dan sesudah melaksanakan tindakan. Hasil belajar siswa secara klasikal, yaitu rata-rata kelas (R) adalah 80, daya serap (DSS) adalah 80\% dan ketuntasan klasikal belajar(KK) 85\%, berdasarkan indeks KKM pada mata pelajaran Seni Budaya sebesar: 78 untuk kelas IX SMP Negeri 3 Banjar semester genap tahun pelajaran 2017/2018.

Apabila sudah dilaksanakan dalam dua siklus maka penelitian dihentikan. Keberhasilan tindakan penelitian dapat dilihat pada Tabel 1 dibawah ini.

Tabel 1. Indikator Keberhasilan Penelitian Tindakan Kelas

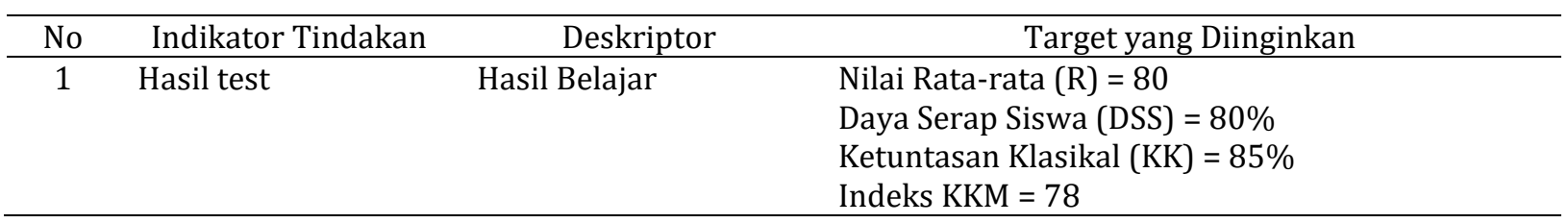

Pengumpulan data dalam penelitian ini yaitu menggunakan metode tes. Berdasarkan metode tersebut, maka instrument yang digunakan dalam penelitian ini yaitu berbentuk butiran soal ulangan tertulis, yaitu berupa soal-soal ulangan dalam tes obyektif pilihan ganda. Data dalam penelitian ini yaitu sumber data primer berasal dari siswa dalam bentuk : 1) Nilai ulangan harian sebelum perbaikan, 1) Nilai ulangan pelaksanaan Siklus I dan 3) Nilai ulangan pelaksanaan Siklus II. Jenis data yang akan didapatkan adalah data kuantitatif. Data kualitatif yaitu hasil observasi antara siswa dalam kelompok pada saat pembelajaran berlangsung, sedangkan data kuantitatif adalah hasil nilai tes.

Metode yang digunakan untuk menganalisis data hasil penelitian ini adalah metode deskriptif kuantitatif, dengan memberi komentar-komentar mengklasifikasikan data, dan selanjutnya membuat kesimpulan refleksi dengan mencari makna dari kesimpulan hubungan antar kategori. 
A. Analisis data kuantitatif, digunakan beberapa rumus yakni :

a. Rata - rata (Mean) dihitung dengan rumus ;

R = \begin{tabular}{c|} 
Jumlah Nilai \\
- Jumlah Siswa
\end{tabular}

b. Daya Serap Siswa (DSS) dihitung dengan rumus ;

\begin{tabular}{l} 
Nilai yang dicapai siswa \\
DSS = ---:----------- x 100\% \\
Nilai maksimum \\
\hline
\end{tabular}

Kriteria keberhasilan tindakan yaitu jika DSS $\geq 80 \%$

c. Ketuntasan Klasikal dihitung dengan rumus ;

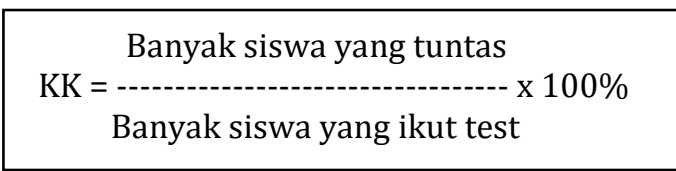

Kriteria keberhasilan tindakan yaitu jika $\mathrm{KK} \geq 85 \%$

d. Median (titik tengah) dicari dengan mengurut data/nilai siswa dari yang terkecil sampai terbesar Kalau jumlahnya genap maka dua data yang ditengah dijumlahkan dibagi 2(dua)

e. Modus (angka yang paling banyak/paling sering muncul) setelah diurut atau asccending

B. Penyajian bentuk grafik, maka hal-hal berikut dihitung terlebih dahulu.

a. Banyak kelas $(\mathrm{K}) \quad=1+3,3 \times \log (\mathrm{N})$

b. Rentang kelas $(\mathrm{r}) \quad=$ skor maksimum - skor minimum

c. Panjang kelas interval (i) $=\frac{r}{k}$

Dalam penelitian ini, tingkat keberhasilan diukur dari rata-rata hasil belajar siswa yakni bila secara individu telah mencapai sama dengan atau melebihi KKM yakni 78, daya serap siswa lebih dari atau sama dengan $80 \%$ dan secara klasikal rata-rata ketuntasan belajar telah mencapai atau melebihi $85 \%$.

\section{Hasil dan Pembahasan}

1. Deskripsi Awal

Sebelum melakukan penelitian dan menerapkan metode pembelajaran yang baru, maka terlebih dahulu peneliti mengambil data awal siswa sebelum diberikan model pembelajaran yang baru. Hal ini bertujuan untuk mengetahui peningkatan yang terjadi saat diberikan model pembelajaran yang baru. Gambaran yang diperoleh dari data awal adalah banyaknya peserta didik yang memperoleh nilai di bawah KKM yaitu 20 siswa (71\%). Hanya ada 8 siswa (29\%) yang mampu memperoleh keberhasilan sesuai harapan. Hal ini merupakan ciri bahwa sebagian besar anak membutuhkan bimbingan dan pengarahan serius untuk dapat meningkatkan perkembangan kemampuan mereka. Untuk lebih jelasnya dapat dilihat pada tabel berikut ini.

Tabel 2 .Nilai Awal Hasil Belajar Seni Budaya pada Siswa Kelas IX.12 Semester Genap SMP Negeri 3 Banjar

\begin{tabular}{lc}
\hline \multicolumn{1}{c}{ Variabel } & Nilai \\
\hline Jumlah Nilai & 1835 \\
Rata-rata (mean) & 65,50 \\
KKM (Kriteria Ketuntasan Minimal) & 78 \\
Jumlah siswa yang diremidi & 20 \\
Jumlah siswa yang diberi pengayaan & 8 \\
\hline
\end{tabular}


2. Siklus I

Sumber: Hasil Pengolahan Data 2018

Pengamatan dilakukan setelah proses pembelajaran dilaksanakan dalam 3 kali pertemuan dengan memberikan tes hasil belajar. Dalam pengamatan ini peneliti mengawasi siswa dengan ketat agar tidak ada siswa yang bekerjasama dalam mengerjakan soal. Waktu pelaksanaan untuk siklus I ini pada minggu ke -3 Bulan Januari 2018. Lebih detailnya adalah pada hari Jumat. tanggal 19 Januari 2018 jam ke 1 - 2 untuk pertemuan pertama, sedangkan pertemuan kedua pada hari Jumat, 26 Januari 2018 jam ke 1-2, selanjutnya hari Jumat, 9 Pebruari 2018. Dalam pengamatan ini peneliti mengawasi siswa dengan ketat agar tidak ada siswa yang bekerjasama dalam mengerjakan soal. Hasil pengamatan pada siklus I peneliti sampaikan pada Tabel 3 berikut ini.

Tabel 3. Nilai Hasil belajar Seni Budaya siswa kelas IX.12 semester Genap SMP Negeri 3 Banjar pada Siklus I

\begin{tabular}{lc}
\hline \multicolumn{1}{c}{ Variable } & skor \\
\hline Jumlah Nilai & 2007 \\
Rata-rata (mean) & 71,68 \\
KKM (Kriteria Ketuntasan Minimal) & 78 \\
Jumlah siswa yang diremidi & 16 \\
Jumlah siswa yang diberi pengayaan & 12 \\
Prosentase ketuntasan belajar & $43 \%$ \\
\hline
\end{tabular}

Refleksi merupakan kajian secara menyeluruh tindakan yang telah dilakukan berdasarkan data yang telah terkumpul, kemudian dilakukan evaluasi guna menyempurnakan tindakan. Refleksi menyangkut analisis, sistesis dan penilaian terhadap hasil pengamatan atas tindakan yang dilakukan (Hopkin, 1993 dalam Suharsimi Arikunto, Suhardjono, Supardi, 2006: 80). Dari data tabel 03 dapat dikatakan bahwa prosentase ketuntasan belajar siswa sebesar $43 \%$ ini meningkat dibandingkan dengan data awal. Adapun kelemahan atau kekuarangan pada Siklus I yaitu:

a. Pelaksanaan pembelajaran belum maksimal akibat kemampuan siswa menerima dan meresapkan materi yang diajarkan belum mampu dioptimalkan.

b. Anak-anak agak sulit dimotivasi untuk giat melaksanakan pembelajaran dikarenakan siswa masih merasa malu dan kurang percaya diri.

c. Guru belum menemukan cara untuk menumbuhkan emosi agar anak lebih percaya diri dalam melakukan tugas-tugas yang diminta.

Sedangkan kelebihan yang ditemukan pada pelaksanaan tindakan siklus I adalah:

a. Bahan pengajaran telah diupayakan persiapannya dengan sebaik-baiknya untuk membantu siswa giat belajar.

b. Pengelolaan kelas sudah diupayakan dan bimbingan terhadap anak juga sudah dilakukan dengan maksimal.

c. Penulis sebagai guru di sekolah ini mampu melihat siswa-siswa yang membutuhkan motivasi lebih banyak lagi dibandingkan siswa yang lainnya.

3. Siklus II

Hasil pengamatan pada siklus II peneliti sampaikan pada Tabel 4 berikut.

Tabel 4. Nilai Hasil belajar seni budaya siswa kelas IX.12 semester Genap SMP Negeri 3 Banjar pada Siklus II

\begin{tabular}{lc}
\hline \multicolumn{1}{c}{ Variabel } & Nilai \\
\hline Jumlah Nilai & 2248 \\
Rata-rata (mean) & 80,29 \\
KKM (Kriteria Ketuntasan Minimal) & 78 \\
Jumlah siswa yang diremidi & 4 \\
Jumlah siswa yang diberi pengayaan & 24 \\
Prosentase ketuntasan belajar & $86 \%$ \\
\hline
\end{tabular}


Kuantitatif hasil Belajar siswa siklus II

1. Rata-rata (mean) dihitung dengan:

2. Daya $\quad \mathrm{R}=\frac{\text { jumlah } \text { nilai }}{\text { jumlah siswa }}=\frac{2248}{28}=80,29 \quad$ Serap Siswa

$$
\mathrm{DS}=\frac{\text { Target Kurikulum } \times \mathrm{RNR}}{100}=\frac{80 \% \times 80}{100}=64,00 \%
$$

3. Ketuntasan klasikal(KK)

$$
\mathrm{KK}=\frac{\text { jumlah siswa tuntas }}{\text { jumlah siswa }} \times 100 \%=\frac{24}{28} \times 100 \%=85,71
$$

4. Median (titik tengahnya) dicari dengan mengurut data/ nilai siswa dari yang terkecil sampai terbesar. Setelah diurut, apabila jumlah data ganjil maka mediannya adalah data yang ditengah. Kalau jumlahnya genap maka dua data yang ditengah dijumlahkan dibagi 2 (dua). Untuk median yang diperoleh dari siklus I dengan menggunakan cara tersebut adalah:

$$
\frac{80+80}{2}=80
$$

5. Modus (angka yang paling banyak/ paling sering muncul) setelah di asccending / diurut angka tersebut adalah: 80

6. Untuk persiapan penyajian dalam bentuk grafik maka hal-hal berikut dihitung terlebih dahulu.

(a) Banyak kelas $(\mathrm{K}) \quad=1+3,3 \times \log (\mathrm{N})$

$$
\begin{aligned}
& =1+3,3 \times \log 28 \\
& =1+(3,3 \times 1,45) \\
& =1+4,78 \\
& =5,78 \rightarrow 6
\end{aligned}
$$

(b) Rentang kelas (r) = skor maksimum - skor minimum

$$
\begin{aligned}
& =90-65 \\
& =25
\end{aligned}
$$

(c) Panjang kelas interval (i) $=\frac{r}{k}=\frac{25}{6}=4.16 \rightarrow 4$

Tabel 5. Data Kelas Interval Siklus II

\begin{tabular}{ccccc}
\hline $\begin{array}{c}\text { No } \\
\text { Urut }\end{array}$ & Interval & Nilai Tengah & $\begin{array}{c}\text { Frekuensi } \\
\text { Absolut }\end{array}$ & $\begin{array}{c}\text { Frekuensi } \\
\text { Relatif }\end{array}$ \\
\hline 1 & $65-68$ & 66.5 & 1 & 3.58 \\
2 & $69-72$ & 70.5 & 3 & 10.71 \\
3 & $73-76$ & 74.5 & 6 & 21.43 \\
4 & $77-80$ & 78.5 & 8 & 28.57 \\
5 & $81-84$ & 82.5 & 0 & 0.00 \\
6 & $85-88$ & 86.5 & 7 & 25 \\
7 & $89-92$ & 90.5 & 3 & 10.71 \\
& Total & & 28 & 100 \\
\hline
\end{tabular}

Data awal yang diperoleh dengan rata-rata 65,50 menunjukkan bahwa kemampuan anak/siswa pada mata pelajaran seni budaya masih sangat rendah mengingat kriteria ketuntasan belajar siswa untuk mata pelajaran ini di SMP Negeri 3 Banjar adalah 78.

Dengan nilai yang sangat rendah seperti itu, maka peneliti mengupayakan untuk dapat meningkatkan hasil belajar siswa menggunakan Model Pembelajaran Problem Solving, Berbantuan Latihan Keterampilan (Drill Method). Akhirnya dengan Penerapan Model Pembelajaran Problem Solving, Berbantuan Latihan Keterampilan (Drill Method) yang benar sesuai teori yang ada, peningkatan rata-rata hasil belajar seni budaya siswa pada siklus I dapat diupayakan dan mencapai rata-rata 71,68. 
Namun rata-rata tersebut belum maksimal karena hanya 12 siswa memperoleh nilai diatas KKM, sedangkan yang lainnya belum mencapai KKM. Sedangkan persentase ketuntatasan belajar mereka baru mencapai 43\%. Hal tersebut terjadi akibat penggunaan Model Pembelajaran Problem Solving, Berbantuan Latihan Keterampilan (Drill Method) yang belum maksimal dilakukan, hal ini disebabkan penerapan metode tersebut baru dicobakan sehingga guru masih belum mampu melaksanakannya sesuai alur teori yang benar. Sehingga dianggap perlu untuk melanjutkan ke siklus II dan memperbaiki kelemahan yang terdapat pada siklus I.

Pada siklus II perbaikan hasil belajar seni budaya siswa diupayakan lebih maksimal dengan peneliti membuat perencanaan yang lebih baik, menggunakan alur dan teori dari Model Pembelajaran Problem Solving, Berbantuan Latihan Keterampilan (Drill Method) dengan benar dan lebih maksimal.

Peneliti giat memotivasi siswa agar giat belajar, memberi arahan-arahan, menuntun mereka untuk mampu menguasai materi pada mata pelajaran seni budaya lebih optimal. Akhirnya dengan semua upaya tersebut peneliti mampu meningkatkan prestasi belajar seni budaya siswa pada siklus II menjadi rata-rata 80,29 dengan persentase ketuntasan sebesar $86 \%$.

Upaya-upaya yang maksimal tersebut menuntun kepada penelitian bahwa Model Pembelajaran Problem Solving, Berbantuan Latihan Keterampilan (Drill Method) dapat meningkatkan hasil belajar dalam mata pelajaran seni budaya. Dari semua data yang diperoleh, ternyata indikator keberhasilan penelitian yang menuntut $80 \%$ lebih sudah mampu mencapai ketuntasan belajar. Oleh karenanya penelitian ini tidak dilanjutkan ke siklus berikutnya

\section{Simpulan Dan Saran}

Penelitian Berdasarkan semua kegiatan yang telah dilaksanakan baik pelaksanaan awal, pelaksanaan siklus I maupun pelaksanaan siklus II berikut semua hasil-hasil yang telah diperoleh dapat disampaikan simpulan: 1) Model Pembelajaran Problem Solving, Berbantuan Latihan Keterampilan (Drill Method). mampu membuat siswa belajar aktif, senang, dan mampu menggairahkan mereka untuk giat belajar, lebih berkonsentrasi, membuat daya pikir mereka lebih berkembang, dapat membuat suasana belajar lebih nyaman, siswa lebih berani menyampaikan pendapat dan mampu memahami lebih dalam apa yang diajarkan. 2) Model Pembelajaran Problem Solving, Berbantuan Latihan Keterampilan (Drill Method) sangat efektif dalam memecahkan masalah pembelajaran apabila mampu dilakukan dengan baik, begitu pula apabila guru mampu menerapkan teori yang benar sesuai metode tersebut. 3) Bukti-bukti berikut dapat dipakai acuan dalam menjawab perncapaian peningkatan proses pembelajaran dan peningkatan prestasi peserta didik: (1) Dari data awal ada 20 siswa mendapat nilai dibawah KKM dan pada siklus I menurun menjadi 16 siswa dan siklus II hanya 4 siswa mendapat nilai di bawah KKM. (2) Nilai rata-rata awal 65,50 naik menjadi 71,68 pada siklus I dan pada siklus II naik menjadi 80,29. (3) Dari data awal siswa yang tuntas hanya 8 orang sedangkan pada siklus I menjadi lebih banyak yaitu 12 siswa dan pada siklus II menjadi cukup banyak yaitu 24 siswa.

Paparan di atas membuktikan bahwa Model Pembelajaran Problem Solving, Berbantuan Latihan Keterampilan (Drill Method) dapat memberi jawaban sesuai tujuan penelitian ini. Semua ini dapat dicapai karena Model Pembelajaran Problem Solving, Berbantuan Latihan Keterampilan (Drill Method) sangat efektif diterapkan dalam proses pembelajaran yang mengakibatkan siswa aktif, antusias dan dapat memahami materi yang diajarkan sehingga hasil belajar seni budaya siswa menjadi meningkat.

Berdasarkan simpulan tersebut dapat disarankan beberapa hal yaitu: 1) Dalam melaksanakan pembelajaran disarankan agar guru-guru membuat persiapan yang matang dan mampu menentukan atau memilih topik yang benar-benar bisa diterapkan dengan Model Pembelajaran Problem Solving, Berbantuan Latihan Keterampilan (Drill Method) agar diperoleh hasil yang optimal. 2) Disarankan bagi guru yang ingin meningkatkan hasil belajar siswa, hendaknya lebih sering melatih siswa dengan kegiatan penemuan, walau dalam taraf yang sederhana, di mana siswa nantinya dapat menemukan pengetahuan baru, memperoleh konsep dan keterampilan, sehingga siswa berhasil atau mampu memecahkan masalahmasalah yang dihadapinya. Serta dilakukan latihan-latihan keterampilan yang menunjang berkembangnya wawasan siswa. Dan 3) Perlu adanya penelitian yang lebih lanjut, karena hasil penelitian ini hanya dilakukan di SMP Negeri 3 Banjar tahun pelajaran 2017/2018.

\section{Daftar Rujukan}

Abdul. 2002. http://www.scribd.com/doc/9037208/

Adnyani, Nyoman. 2002. Kelemahan-Kelemahan Penerimaan Siswa SMP yang Beracuan pada NUAN. Makalah yang Disampaikan dalam Seminar Ilmiah Universitas Mahasaraswati, September 2003. 
Anastasi, Anne. 1976. Psychological Testing. Fifth Edition.New York: Macmillan Publishing Co., Inc.

Ardana, Nengah. 1999. Hubungan antara Motivasi Belajar dan Pola Pemberian Tugas dengan Prestasi Belajar Bidang Studi Fisika pada Siswa SMP Negeri 1 Denpasar. Skripsi. IKIP Mahasaraswati Tabanan.

Arikunto, Suharsimi; Suhardjono; Supardi. 2006. Penelitian Tindakan Kelas. Jakarta: PT Bumi Aksara.

Aryana, Wayan. 2003. Pengaruh Motivasi Belajar terhadap Prestasi Belajar IPA pada Siswa SMP Negeri 1 Denpasar. Ringkasan Hasil Penelitian yang Disampaikan dalam Seminar Hasil Penelitian Dosen Kopwil VIII, Tanggal 22-24 September 2003.

Asmani, Jamal Ma’mur. 2009. 7 Tips Aplikasi PAKEM. Jogjakarta: DIVA Press.

Azwar, Saifuddin. 2003. Penyusunan Skala Psikologi. Yogyakarta: Pustaka Pelajar.

Badan Standar Nasional Pendidikan. 2007. Peraturan Menteri Pendidikan Nasional Republik Indonesia Nomor 41 Tahun 2007. Jakarta: BSNP.

Bakry, N.M. 1986. Logikci Praktis. Yogyakarta: Liberty.

Budiadnya, Made. 2004. Ujicoba Model Pembelajaran Generatif dalam Pembelajaran Pendidikan Pancasila dan Kewarganegaraan (PPKn) di SMP Negeri 5 Singaraja. Tesis. Singaraja: Program Pascasarjana IKIP Negeri Singaraja.

Budiadnyana, Putu. 2004. Pengaruh Model Pembelajaran Kooperatif Bermodul yang Berwawasan SMK Terhadap Hasil Belajar Biologi (Eksperimen pada Siswa Kelas II SD di Singaraja). Disertasi. Program Pascasarjana Universitas Negeri Malang.

Dahar, Ratna Wilis. 1989. Teori-Teori Belajar. Jakarta: Penerbit Erlangga.

Departemen Pendidikan Nasional. 2003. Kurikulum 2004. Jakarta: Depdiknas.

Depdikbud. 1984/1985. Program Akta Mengajar V-B Komponen Dasar Kependidikan: Penilaian Program Pendidikan. Jakarta: Universitas Terbuka.

Depdikbud.1994. Petunjuk Pelaksanaan Proses Belajar-Mengajar. Jakarta: Direktorat Pendidikan Menengah Umum.

Depdikbud.1996. Petunjuk Teknis Mata Pelajaran IPS-Sejarah. Jakarta: Direktorat Pendidikan Menengah Umum.

Depdiknas,2002a. Pedoman Umum Sistem Pengujian Hasil KBM Berbasis Kemampuan Dasar. Dirjen Dikdasmen.

Dimyati dan Mudjiono. 2001. Belajar dan Pembelajaran. Jakarta: Dirjen Dikti.

Direktorat Tenaga Kependidikan, Direktorat Jendral Peningkatan Mutu Pendidik dan Tenaga Kependidikan. 2008. Metode dan Teknik Supervisi. Jakarta: Depdiknas.

Djamarah, Syaful Bahri. 2002. Prestasi Belajar dan Kompetensi Guru. Surabaya: Usaha Nasional.

Fernandes, H.J.X. 1984. Testing and Measurement. Jakarta. National Education Planning, Evaluation and Curriculum Development.

Fraenkel, Jack R. and Norman E. Wallen. 1993. How to Design and Evaluate Research in Education. Second Edition. New York: McGraw-Hill, Inc. 
Gagne, Robert M. 1977. The Conditions of Learning. Third Edition. New York: Holt, Reinhart and Winston.

Gallagher, Shelagh A \& Stepien. William J. 1995. Implementing Problem Based Learning in Science Classroom. School Science and Mathemathic.

Gay, L. R. 1987. Educational Research: Competencies for Analysis and Application. Seventh Edition. Columbus, Ohio: Merrill Publishing Company.

Good, Thomas L. \& Jere E. Brophy. 1990. Educational Psychology, A Realistic Approach. New York: Longman.

Gregory, Robert J. 2000. Psychological Testing: History, Principles, and Applications. Boston: Allyn and Bacon.

Gronlund, Norman E. 1982. Constructing Achievement Tests. Third Edition. London: Prentice-Hall, Inc., Englewood Cliffs.

Hamalik, Oemar. 2002. Psikologi Belajar dan Mengajar. Bandung: Sinar Baru.

Hamdani, M.A. 2009. Strategi Belajar Mengajar. Bandung: CV. Pustaka Setia.

Herrhyanto, Nar dan Hamid, Akib. 2006. Statistika Dasar. Jakarta: Universitas Terbuka.

Hilke, Eileen Veronica. 1998. Fastback Cooperative Learning. New York: McGraw-Hill, Inc.

http://psychemate.blogspot.com/2007/12/problem-solving.html. Diakses tanggal 28 April 2011.

http://education-mantap.blogspot.com/2010/10/teori-problem-solving.html. Diakses tanggal 28 April 2011.

Inten, I Gede. 2004. Pengaruh Model Pembelajaran dan Pengetahuan Awal Siswa Terhadap Prestasi Belajar PKn dan Sejarah pada Siswa Kelas II di SMU Laboratorium IKIP Negeri Singaraja. Tesis. Program Pascasarjana IKIP Negeri Singaraja.

Irianto, Agus. 1989. Bahan Ajaran Statistika Pendidikan (Buku Kedua). Jakarta: Proyek Pengembangan Lembaga Pendidikan Tenaga Kependidikan.

Johnson and R.T. Johnson. 1987. Learning Together and Alone: Cooperation, Competition, and Individualistic Learning. Englewood Cliffs, N.J.: Prentice-Hall.

Johnson, David W. and Roger T. Johnson. 1984. Cooperation in the Classroom. Edina,Minnesota: A publication Interaction Book Company.

Johnson,1984. Circles of Learning. Fairfax, Va.: Association for Supervision and Curriculum Development.

Liasari. 2000. Model Pembelajaran untuk Meningkatkan Keterampilan Berpikir Konseptual Tingkat Tinggi Calon Guru IPA. Proseding Seminar Nasional 23 Pebruari 2000. Malang: Dirjen Dikti Depdiknas -JICA - IMSTEP.

Lickona, Thomas. 1992. Educating For Character. How Our Schools Can Teach Respect and Responsibility.New York: Bantam Books.

Lie, Anita. 2002. Cooperative Learning: Mempraktikkan Cooperative Learning di Ruang-Ruang Kelas. Jakarta: PT Gramedia Widiasarana Indonesia.

Maba, Wayan. 2002. Evaluasi Pembelajaran. Makalah yang disampaikan dalam penataran PBM Dosen Kopertis Wilayah VIII, Tanggal 27-30 Oktober 2002. 
Marhaeni, A.A.I.N. 2005. Pengaruh Asesmen Portofolio dan Motivasi Berprestasi dalam Belajar Bahasa Inggris Terhadap Kemampuan Menulis Bahasa Inggris (Studi Eksperimen pada Mahasiswa Jurusan Pendidikan Bahasa Inggris IKIP Negeri Singaraja, 2004). Desertasi: IKIP Negeri Jakarta.

Miles, Matthew, B. Dan A. Michael Hubberman. 1992. Analisis Data Kualitatif. Terjemahan Tjetjep Roheadi Rohidi. Jakarta: Penerbit Universitas Indonesia.

Modern Educators and Lexicographers. 1939. Webster's New American Detionary. New York: 140 Broadway, Books, Inc.

Montgomery, Douglas C. 1991. Design and Analysis of Experiments. Third Edition. Canada: John Willy \& Sons, Inc.

Murwani, S. 1999. Statistik Terapan (Terkait Analisis Data). Jakarta: Erlangga.

Murwansyah dan Mukaram. 2002. Manajemen Sumber Daya Manusia. Bandung: Pusat Penerbit Administrasi Niaga Politeknik Negeri Bandung, Indonesia.

Nana Sudjana. 2000. http//www.scribd.com/doc/9037208/

Nasution, S. 1972. Didaktik Sekolah Pendidikan Guru: Asas-Asas Didaktik Metodologi Pengajaran dan Evaluasi. Depdikbud: Jakarta.

Nur, Mohamad et al. 2001. Teori Belajar. Surabaya: University Press.

Nurkancana, Wayan dan P.P.N. Sunartana. 1990. Evaluasi Pendidikan.Surabaya: Usaha Nasional.

Peraturan Menteri Pendidikan Nasional No. 41 Tahun 2007 Tanggal 23 November 2007. Jakarta: Depdiknas.

Popham, W. James dan Eva L. Baker. 1984. Bagaimana Mengajar Secara Sistematis. Diterjemahkan Oleh R.H. Dj. Sinurat et al.Yogyakarta: Kanisius.

Puger, I Gusti Ngurah. 2004. Belajar Kooperatif. Diktat Perkuliahan Mahasiswa Unipas.

Puger, I Gusti Ngurah. 2004. Pengaruh Metode Pembelajaran dan Kemampuan Berpikir Silogisme Terhadap Prestasi Belajar Biologi pada Siswa Kelas III SMP Negeri Seririt (Eksperimen pada Pokok Bahasan Reproduksi Generatif Tumbuhan Angiospermae). Tesis. Program Pascasarjana IKIP Negeri Singaraja.

Pujiono, 2009. Metode Drill dan Penggunaannya. Tersedia online http://jindauksw.blogspot.com/2009/11/metode-drill-dan-penggunaannya. html

Purwanto, Ngalim. 1997. Psikologi Pendidikan. Bandung: Rosdakarya.

Sahertian, Piet A \& Aleida Sahertian. 1992. Supervisi Pendidikan dalam Rangka Program Inservice Education. Jakarta: Rineka Cipta.

Sardiman, A.M. 1988. Interaksi dan Motivasi Belajar-Mengajar Pedoman bagi Guru dan Calon Guru.Jakarta: Rajawali Pers.

Sax, Gilbert. 1979. Foundations of Educational Research. New Jersey: Prentice-Hall, Inc., Englewood Cliffs.

Silverius, Suke. 1991. Evaluasi Hasil Belajar dan Umpanbalik. Jakarta: PT Grasindo.

Slameto. 2000. Belajar dan Faktor-Faktor yang Mempengaruhinya. Jakarta: Rineka Cipta.

Slavin, Robert E. 1995. Cooperative Learning : Theory, Research, and Practice.Boston: Allyn and Bacon. 
Soedomo, M. 2001. Landasan Pendidikan. Malang: Penyelenggaraan Pendidikan Pascasarjana Proyek Peningkatan Perguruan Tinggi.

Soemanto, Wasty. 2001. Pengantar Psikologi Pendidikan. Surabaya: Usaha Nasional.

Soetomo. 1993. Dasar-Dasar Interaksi Belajar-Mengajar. Surabaya: Usaha Nasional.

Sriyono. 1992. http://www.scribd.com/doc/9037208/

Sudiarta, Wayan. 1996. Pengaruh Penyisipan Berpikir Silogisme dalam Proses Pembelajaran terhadap Prestasi Belajar IPA pada Siswa SMP Negeri 1 Denpasar. Ringkasan Hasil Penelitian yang Disampaikan dalam Seminar Hasil Penelitian Dosen Kopwil VIII, Tanggal 22-24 September 1996.

Sudijono, Anas. 2001. Pengantar Evaluasi Pendidikan. Jakarta: Rajawali Pers.

Sudijono, Anas. 2001. Pengantar Statistik Pendidikan. Jakarta: Rajawali Pers.

Sudjana, Nana. 2002. Penilaian Hasil Proses Belajar Mengajar. Bandung: PT Remaja Rosdakarya.

Sudjana. 1996. Metoda Statistika. Bandung: Tarsito.

Sugiarto et al. 2001. Teknik Sampling. Jakarta: PT Gramedia Pustaka Utama.

Suharsimi, A. 2003. Dasar-dasar Evaluasi. Jakarta: Bumi Aksara.

Sukarta, Wayan. 2005. Pengaruh Pemberian Pretest Terhadap Prestasi Belajar PKPS pada Siswa Kelas V SD Lab. Singaraja. Laporan Penelitian. Denpasar: IKIP PGRI.

Sukidin, Basrowi, Suranto. 2002. Menajemen Penelitian Tindakan Kelas. Penerbti: Insan Cendekia ISBN: 9799048334.

Sumadi Suryabrata. 1995. Psikologi Pendidikan. Jakarta: Raja Grafindo Persada.

Sumadi Suryabrata. 1998. Pengembangan Alat Ukur Psikologis. Dirjen Dikti Depdiknas.

Supardi, 2005. Pengembangan Profesi dan Ruang Lingkup Karya Ilmiah. Jakarta: Depdiknas.

Suryabrata, Sumadi. 2000. Pengembangan Alat Ukur Psikologis. Yogyakarta: Penerbit Andi.

Tim Prima Pena. Kamus Besar Bahasa Indonesia. Gramedia Press.

Tim Redaksi Focus Media. 2006. Undang-Undang Republik Indonesia No. 20 Tahun 2003 tentang Sistim Pendidikan Nasional. Bandung: Focus Media.

Tim Redaksi Fokus Media. 2006. Himpunan Perundang-Undangan dan Undang-Undang Republik Indonesia No. 20 Tahun 2003 dan Peraturan Pemerintah No. 19 Tahun 2005. Bandung: Focus Media.

Tuckman, Bruce W. 1972. Conducting Educational Research. New York: Harcourt Brace Javonovich, Inc.

Universitas Negeri Jakarta. 2000. Aplikasi Komputer: Kalibrasi Instrumen, Pengolahan Data, dan Pemanfaatan Internet. Jakarta: Laboratorium Komputer UNJ.

Uno, B. Hamzah, et. al. 2001. Pengembangan Instrumen Untuk Penelitian. Jakarta: Delima Press.

Wardani, I. G. A. K Siti Julaeha. Modul IDIK 4307. Pemantapan Kemampuan Mengajar. Jakarta: Universitas Terbuka.

Wartawan, I Wayan. 2004. "Pembinaan Kualitas Pembelajaran Fisika Melalui Penerapan Model Pembelajaran Kooperatif Tipe Jigsaw dalam Upaya Meningkatkan Hasil Belajar Siswa Kelas II SMU 
Negeri 2 Singaraja". Dalam Jurnal IKA, Vol. 2 No.1 Mei 2004 Institut Keguruan dan Ilmu Pendidikan Negeri Singaraja.

Wojowasito. 1982. Kamus Umum Lengkap Inggris Indonesia - Indonesia Inggris. Malang: Delta Citra Grafindo.

Woolfolk, Anita E. 1993. Educational Psychology. Fifth Edition. Boston: Allyn and Bacon. 